\title{
CORRELATIONS BETWEEN RED BLOOD CELLS' VARIABLES, CARDIO-PYSIOLOGICAL AND ANTHROPOLOGICAL VARIABLES IN YOUNG ATHLETES
}

\author{
${ }^{1}$ Faculty of Medicine, University Ss. Cyril and Methodius, Skopje, R. N. Macedonia \\ ${ }^{2}$ General Hospital 8 September, Skopje, R. N. Macedonia \\ ${ }^{3}$ Serbian Institute of Sport and Sports Medicine, Belgrade, Serbia
}

Jasmina Pluncevic Gligoroska $^{1}$, Sandra Dejanova ${ }^{2}$, Jadranka Plavsic ${ }^{3}$, Sanja Manchevska ${ }^{1}$

Corresponding author: Prof. Jasmina Pluncevic Gligoroska, MD, PhD; Institute of MEP Physiology and Anthropology, Medical Faculty, Ss. Cyril and Methodius University, Skopje, Republic of North Macedonia, e-mail: jasnapg965@yahoo.com

\section{ABSTRACT}

Aim: The aim of this study was to determine and analyse the relations between anthropometric parameters, red blood cells' (RBC) variables and cardio-physiological parameters in healthy and physically active children and adolescents.

Material and Methods: In this study 625 subjects, (410 males and 215 females; age span 8 to 18 years) underwent body composition analysis (Matiegka method), blood analysis and ergometry testing (Bruce protocol).

Results: In both groups, body height and weight were positively correlated with RBC variables. In female group almost all correlations between RBC variables and body components were insignificant. In boys all absolute body mass components showed positive correlations with RBC variables with notice that body fat mass had lowest correlation coefficient. Body fat percent (BF \%) did not show any correlation with $\mathrm{RBC}$ variables in both gender groups. In boys $\mathrm{BF} \%$ had moderate negative correlation with aerobic performance: exercise time (ET) and VO2max ( $\mathrm{rs}=-0.41$ and $\mathrm{rs}=-0.39$ ). Lean body components showed weak positive correlations with ET and VO2max. RBC count did not show significant correlation with any cardio-physiological parameter in both groups. Haematocrit and haemoglobin showed weak positive correlations with VO2 max and general endurance (exercise time). In girls all correlations between cardio-physiological and $\mathrm{RBC}$ variables were insignificant. The relationship between all body components and all cardio-physiological variables in girls were statistically insignificant.

Conclusions: Our findings revealed that there are some expected positive correlations between lean body mass components, aerobic performance and $\mathrm{RBC}$ variables in boys, while in girls such relations were not noticed.

Keywords: young athletes, body composition, red blood cells' variables, oxygen consumption

\section{INTRODUCTION}

Medical screening of young athletes through the year is an appropriate and necessary approach to safeguard the athlete's health and, simultaneously, determine the implications of the applied training loads on growth and maturation $[1,2]$. Physical activity influences many organic systems in human 
body, as well as the functional and morphological characteristics of these systems have certain effects on the quality and the quantity of physical performance. Satisfactory cardio-physiological, haematological and anthropometric properties have positive effects on sports performance [3-5]. The growth of the body, increasing and changing all body components, has the biggest dynamics during the adolescent period, and reaches its maximum by the end of adolescent period, around 18 years. Blood parameters reach adult values earlier, approximately around the age of 15 [6].

There is some evidence that body size can be associated with some haematological parameters in adults and these relationships were slightly more pronounced in men [7]. The body composition is pointed as one of the factors which contribute to gender relation variations in cardiac functions and maximal oxygen consumption [8]. Investigations on anthropometric factors and haematological parameters showed that anaemia, as well as iron deficiency are often associated with obesity $[9,10]$.

In this study we wanted to determine whether the parameters that are known to be indicators of good health and good physical fitness show mutual association. The aim of this study was to determine and analyse the relationships between anthropometric parameters, RBC variables and cardio-physiological parameters in healthy and physically active children and adolescents.

\section{MATERIAL AND METHODS}

In this study 625 subjects, (410 males and 215 females; age span 8 to 18 years), were included. They attended regular health checks, which comprised laboratory investigation of blood and urine and exercise testing. The studied population was divided by gender in two groups. All subjects or their parents gave their written informed consent to participate in the study. The study was conducted at the Laboratory of sports medicine, at the Institute of Physiology, Medical Faculty at Skopje, RN Macedonia, between September 2016 and March 2017.

\section{Anthropometric measurements}

Body composition was assessed using the classic anthropometric protocol by Matiegka. Participants' height was measured to the nearest $0.1 \mathrm{~cm}$ with a fixed stadiometer (Holtain Ltd., Crymich, U.K.), body weight to the nearest $0.1 \mathrm{~kg}$ using the
SECA beam balance (Seca, Hamburg, Germany). Harpenden skinfold calliper (British indicators Ltd., Luton) was used to take skinfold thickness with 0.1 $\mathrm{mm}$ accuracy and the ankle diameter was measured using a Vernier calliper. Elastic tape was used to take circumferences with 0.01 accuracy. The final outcomes of the Matiegka protocol are three body components expressed as absolute and relative values: body fat percentage $(\mathrm{BF} \%)$, absolute body fat ( $\mathrm{BF}$ in kilograms), relative muscle mass (MM\%), absolute muscle mass (MM in $\mathrm{kg}$ ), bone mass (BM in $\mathrm{kg}$ ) and relative bone mass (BM\%). Lean body mass (LBM) and body mass index (BMI) were also calculated.

\section{Ergometric procedures}

Participants underwent the standard treadmill exercise testing according to the Bruce sub-maximal protocol along with the ACSM guidelines. The duration time (ET $=$ exercise time) is used to calculate maximal oxygen consumption (VO2max).

\section{Hematologic measurements}

To determine the blood count and RBC variables blood samples were collected from capillary vessel using sterile plastic containers with anticoagulant (EDTA K3) incorporated in its walls. Analysis was made by haematology analyser ABX Micros 60-OT (ABX haematology, Montpelier, France). The following haematological parameters were analysed: RBC - Red blood cells' count, haematocrit (Hct); haemoglobin level $(\mathrm{Hb})$; mean corpuscular volume (MCV); mean corpuscular haemoglobin $(\mathrm{MCH})$ and mean corpuscular haemoglobin concentration (MCHC).

\section{Ethics}

Institutional ethical approval was received from the Ethics Committee of the Medical Faculty, Ss. Cyril and Methodius University - Skopje, the Republic of North Macedonia. Informed consents were obtained from the parents or the subjects.

\section{Statistics}

The data are presented as group means of individual fish values, accompanied with the respective standard deviation (SD). For statistical analyses, software Statistica 7.0 for Windows was used. After checking the normality and homogeneity of variances with Shapiro-Wilk's W test and Levene's test respectively, data were analysed by two-way ANOVA/MANOVA. Whenever the ANOVA dis- 
closed significant results post-hoc Tukey test were applied. Correlation analyses were used to find specific linear associations. Spearman correlation coefficient was used. Differences were considered significant when $\mathrm{p}<0.05$.

\section{RESULTS}

The baseline characteristics of the anthropometric, haematological and cardio-physiologic parameters of the male and female subjects are presented in Tables 1 and 2. All parameters were tested for normality of distribution. The mean age of studied groups was $13.34 \pm 2.69$ years for girls and $12.97 \pm 2.76$ years for boys. The mean weight and height of boys and girls was $54.97 \pm 19 \mathrm{~kg}$ and $162.36 \pm 17.3 \mathrm{~cm}$ vs $52.93 \pm 11.5 \mathrm{~kg}$ and 158.97 $\pm 10.5 \mathrm{~cm}$, respectively. It should be noted that the range of values for height and weight in both groups, was very wide, because of the wide age span of investigated sample (8 to 18 years).

Table 1. Basic anthropometric, hematologic and cardio-physiologic parameters of the boys

\begin{tabular}{|c|c|c|c|c|}
\hline male & Mean & SD & $\min$ & $\max$ \\
\hline age & 12.97 & 2.76 & 8 & 18 \\
\hline $\begin{array}{l}\text { Height } \\
\text { (cm) }\end{array}$ & 162.36 & 17.3 & 110.5 & 196 \\
\hline $\begin{array}{l}\text { Weight } \\
(\mathrm{kg})\end{array}$ & 54.97 & 19 & 29 & 110.5 \\
\hline МM \% & 52.81 & 3.09 & 40.85 & 61.81 \\
\hline MMkg & 29.4 & 10.23 & 9.4 & 60.1 \\
\hline $\mathrm{BM} \%$ & 18.96 & 12.77 & 12.77 & 26.13 \\
\hline BMkg & 10.24 & 2.9 & 1.75 & 23.45 \\
\hline $\mathrm{BF} \%$ & 15.57 & 3.17 & 9.05 & 31.22 \\
\hline BFkg & 8.8 & 4.01 & 2.56 & 31.22 \\
\hline BMI & 20.30 & 3.44 & 13.95 & 31.37 \\
\hline $\begin{array}{l}\text { RBC } \\
\left(10^{12} / \mathrm{dl}\right)\end{array}$ & 5,08 & 0.44 & 3.87 & 6.32 \\
\hline $\mathrm{Hb}(\mathrm{g} / \mathrm{dl})$ & 13.91 & 1.3 & 10.7 & 17.9 \\
\hline Het & 44.11 & 4.08 & 34.0 & 55.8 \\
\hline $\begin{array}{l}\text { HRR } \\
\left(\mathrm{bpm}^{-1}\right)\end{array}$ & 86.03 & 13.33 & 51 & 133 \\
\hline ET (min) & 10.49 & 2.35 & 4.2 & 17.09 \\
\hline $\begin{array}{l}\nabla O_{2 \max } \\
(\mathrm{ml} . \mathrm{kg})\end{array}$ & 39.59 & 6.63 & 22 & 56 \\
\hline
\end{tabular}

Values are mean (SD): MM -muscular mass; BM - bone mass; BF - body fat; RBC- red blood cell count, Hct,- packed cell volume, $\mathrm{Hb}$ - hemoglobin concentration; HRR- heart rate at rest; ET- exercise time; $\mathrm{VO}_{2 \max }-$ maximal oxygen consumption
Table 2. Basic anthropometric, hematologic and cardio-physiologic parameters of the girls

\begin{tabular}{|l|c|c|r|c|}
\hline girls & mean & SD & Min & Max \\
\hline age & 13.34 & 2.69 & 8 & 18 \\
\hline Height $(\mathrm{cm})$ & 158.97 & 10.05 & 122,0 & 179.5 \\
\hline Weight $(\mathrm{kg})$ & 52.93 & 11.5 & 22,0 & 89 \\
\hline MM\% & 53.34 & 3.06 & 37.27 & 62.49 \\
\hline MMkg & 28.6 & 6.38 & 11.56 & 45.8 \\
\hline BM\% & 16.98 & 1.81 & 12.83 & 21.61 \\
\hline BMkg & 8.92 & 1.47 & 3.86 & 13.07 \\
\hline BF\% & 17.71 & 3.0 & 11.06 & 27.66 \\
\hline BFkg & 9.71 & 3.53 & 2.76 & 22.88 \\
\hline BMI & 20.76 & 3.12 & 14.12 & 32.48 \\
\hline RBC (10 $\left.{ }^{12} / \mathrm{l}\right)$ & 4.79 & 0.4 & 3.87 & 6.29 \\
\hline Hb (g/dl) & 12.9 & 1.04 & 9.5 & 15.3 \\
\hline Hct & 41.17 & 3.26 & 33.46 & 49.4 \\
\hline HRR (bpm $\left.{ }^{-1}\right)$ & 96.01 & 13.78 & 64 & 136 \\
\hline ET (min) & 7.7 & 2.14 & 3.12 & 13.2 \\
\hline VO ${ }_{\text {2max }}\left(\mathrm{ml}^{\circ} \mathrm{kg}\right)$ & 29.86 & 6.29 & 18 & 45 \\
\hline
\end{tabular}

Values are mean (SD): $\mathrm{MM}$-muscular mass; $\mathrm{BM}-$ bone mass; $\mathrm{BF}$ - body fat; RBC- red blood cell count, Hct,- haematocrit, $\mathrm{Hb}$ - hemoglobin concentration; HRR- heart rate at rest; ET- exercise time; $\mathrm{VO}_{2 \max }-$ maximal oxygen consumption.

The analysis showed that mean values of all analysed parameters fell within normal range for healthy children. Only $0.5 \%$ from males ( 2 boys) and from girls (1 girl) had haemoglobin concentration lower than $11 \mathrm{~g} / \mathrm{dl}$, which is the threshold for the diagnosis of anaemia. Regarding haematocrit levels, none of the girls was under the reference value of 35 , while $6 \%$ of boys had Hct $<35$. None of the subjects, of both genders, showed RBC count lower than $3.8 \times 1012 / 1$. All subjects had well developed muscular mass, $>45 \%$. Empirically, normal range for body fat percent (BF \%) by Matiegka is between $12 \%$ and $20 \%$. Only $0.5 \%$ of boys $(n=2)$ and girls $(n=1)$ showed such low $B F \%$ value. In girls $1 \%(n=2)$ and in boys $9 \%(n=40)$ had BF \% higher than 20\%. Extremely high BF $\%(>30 \%)$ was found in $0.5 \%$ of boys and none in girls. BMI higher than 25 was found in one girl $(0.5 \%)$ and in 31 boys $(7.4 \%)$. BMI higher than 30 was not found in the female group, while in boys $2.4 \%(n=9)$ showed such high BMI.

Results of Spearman correlation for relationship between anthropometric data and RBC variables are shown in Table 3 . RBC variables were in positive moderate to strong associations with age in boys, while girls showed weak neg- 
ative association between RBC count and age. Height and weight showed positive correlation with all RBC variables in both groups, in boys with moderate and in girls with weak level of intensity. In boys all absolute body components, muscular, bone and fat, showed moderate to strong positive correlations with $\mathrm{RBC}$ variables. The strongest correlation was found between absolute bone mass and RBC variables: with RBC count $(\mathrm{r}=0.72)$; with $\mathrm{Hb}(\mathrm{r}=0.57)$ and with $\mathrm{Hct}$ $\mathrm{r}=0.61$ ). Absolute muscular mass, $\mathrm{MM} \mathrm{kg}$, showed stronger correlation with $\operatorname{Hct}(\mathrm{r}=0.61)$, than with Hb level $(r=0.59)$ and RBC $(r=0.45)$. Body fat mass (BF kg) showed also positive, but weaker correlation: $\mathrm{RBC}, \mathrm{r}=0.38$, for haemoglobin $\mathrm{r}=$ 0.45 and for haematocrit $r=0.48$.

Table 3. Results of the Spearman correlation coefficient (r) for a relationship between anthropometric and $R B C$ variables
Only body fat percent (BF \%) in boys showed statistically significant correlation with all cardio-physiological parameters. Heart rate at rest (HRR) showed weak positive correlation with $\mathrm{BF} \%$, until exercise time (ET) and VO2 max showed moderate negative correlation with BF \% $(r=-0.41$ and $r=-0.39)$. In girls all correlations between these two groups of parameters were insignificant.

Results of analysis of relationship between haematological and cardio-physiological parameters are shown in table 5. Heart rate in girls showed weak positive correlation with RBC, haemoglobin level and haematocrit $(\mathrm{r}=0.20$; $\mathrm{r}=0.24 ; \mathrm{r}=0.24$ ) while in boys these correlations were statistically insignificant. Haemoglobin and haematocrit showed weak positive correlation with exercise time and VO2max only in boys ( $\mathrm{r}$ $=0.25$ and $\mathrm{r}=0.21$ ).

\begin{tabular}{|c|c|c|c|c|c|c|}
\hline & \multicolumn{2}{|l|}{ RBC } & \multicolumn{2}{|l|}{$\mathrm{Hb}$} & \multicolumn{2}{|l|}{ Het } \\
\hline gender & Male & female & Male & female & Male & female \\
\hline age & $\mathrm{r}=0.42^{*}$ & $\mathrm{r}=-0.16^{* * *}$ & $\mathrm{r}=0.60^{*}$ & n.s & $\mathrm{r}=0.59$ & n.s \\
\hline Height $(\mathrm{cm})$ & $\mathrm{r}=0.57 *$ & $\mathrm{r}=0.27 *$ & $\mathrm{r}=0.59^{*}$ & $\mathrm{r}=0.21^{*}$ & $\mathrm{r}=0.57 *$ & $\mathrm{r}=0.17^{*}$ \\
\hline Weight (kg) & $\mathrm{r}=0.62 *$ & $\mathrm{r}=0.32 *$ & $\mathrm{r}=0.68^{*}$ & $\mathrm{r}=0.32^{*}$ & $\mathrm{r}=0.68^{*}$ & $\mathrm{r}=0.22 *$ \\
\hline MMkg & $\mathrm{r}=0.45^{*}$ & $\mathrm{r}=-0.20 * *$ & $\mathrm{r}=0.59 *$ & n.s. & $\mathrm{r}=0.61 *$ & n.s. \\
\hline MM \% & $\mathrm{r}=0.19 *$ & n.s. & $\mathrm{r}=0.37^{*}$ & n.s & $\mathrm{r}=0.31 *$ & n.s \\
\hline BMkg & $\mathrm{r}=0.72 *$ & $\mathrm{r}=-0.16^{* * *}$ & $\mathrm{r}=0.57^{*}$ & n.s & $\mathrm{r}=0.61^{*}$ & n.s \\
\hline $\mathrm{BM} \%$ & $\mathrm{r}=-0.27^{*}$ & n.s. & $\mathrm{r}=-0.27^{*}$ & n.s. & $\mathrm{r}=-0.25^{*}$ & n.s. \\
\hline BFkg & $\mathrm{r}=0.38 * *$ & $\mathrm{r}=-0.14 * * *$ & $\mathrm{r}=0.45^{*}$ & n.s & $\mathrm{r}=0.48^{*}$ & n.s \\
\hline $\mathrm{BF} \%$ & n.s. & n.s. & n.s. & n.s & n.s. & n.s \\
\hline LBM & $\mathrm{r}=0.46^{*}$ & $\mathrm{r}=-0.21^{* *}$ & $\mathrm{r}=0.58^{*}$ & n.s & $\mathrm{r}=0.61^{*}$ & n.s \\
\hline BMI & $\mathrm{r}=0.45^{*}$ & $\mathrm{r}=-0.14 * * *$ & $\mathrm{r}=0.58 *$ & n.s & $\mathrm{r}=0.61 *$ & n.s \\
\hline
\end{tabular}

${ }^{*} \mathrm{p}<0.001 ;{ }^{* *} \mathrm{p}<0.01 ; * * * \mathrm{p}<0.05 ;$ n.s - non significant

Values are mean (SD): MM -muscular mass; BM bone mass; $\mathrm{BF}$ - body fat; RBC- red blood cell count, Hct,- haematocrit, $\mathrm{Hb}$ - hemoglobin concentration; HRR- heart rate at rest

In girls $\mathrm{RBC}$ count was in negative weak correlation with all body components, lean body mass and body mass index. Haemoglobin and haematocrit showed weak or statistically insignificant correlations with all anthropometric measurements. Results of relationship between anthropometric data and cardio-physiological parameters are shown in table 4 . In girls there were no associations between age and cardio-physiological parameters. In boys HRR was negatively correlated $(\mathrm{r}=-0.14)$ with age while ET and maximal oxygen consumption were positively correlated with age $(r=0.35 ; r=0.40)$.

\section{DISCUSSION}

In this study, correlations between haematological, anthropometric and cardio-physiological parameters were investigated in healthy preadolescent and adolescent boys and girls who are involved in regular physical activity. Our findings revealed that across the age span of 8 to 18 years, body height and weight were positively correlated with RBC variables in male (moderate to strong correlations) and female participants (weak correlations). The relationship between body components (absolute and relative components) and red blood cells' variables also showed 
Table 4. Results of the Spearman correlation coefficient (r) for a relationship between anthropometric and cardio-physiological parameters

\begin{tabular}{|c|c|c|c|c|c|c|}
\hline & \multicolumn{2}{|l|}{ HRR } & \multicolumn{2}{|l|}{ ET } & \multicolumn{2}{|l|}{$\mathrm{VO} 2 \mathrm{max}$} \\
\hline gender & Male & female & Male & female & Male & female \\
\hline age & $\mathrm{r}=-0.13 * *$ & n.s. & $\mathrm{r}=0.35 *$ & n.s. & $\mathrm{r}=0.40 *$ & n.s. \\
\hline Height cm) & n.s & n.s. & $\mathrm{r}=0.22 *$ & n.s & $\mathrm{r}=0.21 *$ & n.s. \\
\hline Weight kg) & n.s. & n.s. & n.s. & n.s. & n.s. & n.s. \\
\hline MMkg & n.s. & n.s. & $\mathrm{r}=0.12 \quad * * *$ & n.s. & $\mathrm{r}=0.13 * * *$ & n.s. \\
\hline MM\% $\%$ & n.s & n.s & n.s & n.s. & n.s. & n.s \\
\hline BMkg & n.s. & n.s. & $\mathrm{r}=0.18 \quad * *$ & n.s. & $\mathrm{r}=0.18 * *$ & n.s. \\
\hline BM\% $\%$ & n.s. & n.s. & n.s. & n.s. & n.s. & n.s. \\
\hline BFkg & n.s. & n.s. & n.s. & n.s. & n.s. & n.s \\
\hline $\mathrm{BF} \%$ & $\mathrm{r}=0.19 *$ & n.s & $\mathrm{r}=-0.41 *$ & n.s. & $\mathrm{r}=-0.39 \quad *$ & n.s. \\
\hline LBM & n.s. & n.s. & $\mathrm{r}=0.16 \quad * *$ & n.s. & $\mathrm{r}=0.15 \quad * *$ & n.s. \\
\hline BMI & n.s & n.s. & $\mathrm{r}=0.16$ & n.s. & $\mathrm{r}=0.15 \quad * *$ & n.s. \\
\hline
\end{tabular}

Values are mean (SD): MM -muscular mass; BM - bone mass; BF - body fat; HRR- heart rate at rest; ETexercise time; $\mathrm{VO}_{2 \max }$ - maximal oxygen consumption.

Table 5. Results of the Spearman correlation coefficient ( $r$ ) for a relationship between cardio-physiological parameters and RBC variables

\begin{tabular}{|c|c|c|c|c|c|c|}
\hline & \multicolumn{2}{|l|}{$\mathrm{RBC}$} & \multicolumn{2}{|l|}{$\mathrm{Hb}$} & \multicolumn{2}{|l|}{ Hct } \\
\hline gender & Male & female & Male & female & Male & female \\
\hline HRR & n.s & $\mathrm{r}=0.20 * * *$ & n.s & $\mathrm{r}=0.26^{* * *}$ & n.s & $\mathrm{r}=0.20 * *$ \\
\hline ET & n.s. & n.s. & $\mathrm{r}=0.25 \quad *$ & n.s. & $\mathrm{r}=0.17 *$ & n.s. \\
\hline $\mathrm{VO}_{2 \text { max }}$ & n.s. & n.s. & $\mathrm{r}=0.21 \quad *$ & n.s. & $\mathrm{r}=0.21 *$ & n.s. \\
\hline
\end{tabular}

Values are expressed as Spearman R value ( $\mathrm{p}$ value), according to the Spearman Rank Order Correlations

Values are mean (SD): RBC- red blood cell count, Hct,- haematocrit, Hb - hemoglobin concentration; HRRheart rate at rest; ET- exercise time; $\mathrm{VO}_{2 \max }-$ maximal oxygen consumption.

positive, weak to moderate intensity in boys. All absolute body components were positively associated to $\mathrm{RBC}$ variables. The body fat mass showed weaker correlation than BMI, LBM (lean body mass) and other lean components (muscular and bone components). Body fat percent (BF \%) did not show any correlation with RBC variables in both gender groups.

In girls only RBC showed very weak negative correlations with all absolute body components. All other correlations between body components and haemoglobin and haematocrit were insignificant in girls. While $\mathrm{RBC}$ variables showed significant positive correlation with age, there were no such findings in girls, except very weak negative correlation between RBC and age.

The relationship between all body components and all cardio-physiological variables in girls were statistically insignificant. Regarding the correlations between cardio-physiological parameters and age, boys showed very weak associations with heart rate at rest which could suggest that younger boys could have higher HRR. In boys lean components (muscle mass, bone mass, LBM) and BMI showed very weak positive correlations (rs lower than 0.19) with oxygen consumption and testing time. Body fat percent and heart rate at rest (HRR) showed very weak positive correlations $(\mathrm{rs}=0.19)$ which could suggest that boys with higher $\mathrm{BF} \%$ could have higher $\mathrm{HR}$ at rest. In boys $\mathrm{BF} \%$ had moderate negative correlation with ET and VO2max ( $\mathrm{rs}=-0.41$ and $\mathrm{rs}=-0.39$ ), which could indicated that boys with higher $\mathrm{BF} \%$ terminated aerometry testing in shorter time and had lower oxygen consumption. 
Red blood cells' count, which is the most prominent RBC variable did not show any correlations with cardio-physiological parameters in both groups. Haemoglobin and haematocrit showed weak positive correlation with aerobic performance variables, ET and VO2max, only in boys.

Absence of significant correlations between anthropometric and haematological variables with cardio-physiological variables in girls should be result of unsatisfactory ergometry outcomes.

One of the very few longitudinal studies which examined longitudinal changes of RBC variables related to body size, during aging, showed that taller men had significantly higher red blood cells' count than shorter men in some age categories (U45, U50). There was a moderate positive correlation between RBC and body weight in men and weak positive correlation in women [7]. Currently, there is certain inconsistency in published reports regarding the relation between BMI and haematological parameters. Most of the reports show positive correlation between BMI and some of the RBC variables. Other studies show different results depending on the BMI classification of the subjects, and depending on the fact if the high BMI is a result of well-developed muscle mass or it is a result of high percentage of body fat. Research on association between haematological parameters and BMI in the general population showed that haematological parameters when adjusted for sex, age and smoking habits, were positively associated with BMI. In the same study, when haematological parameters were adjusted to metabolic profiles (NOMA) the association between haematological parameters and BMI became substantially weaker [11]. Remarkable strong positive linear association was found between $\mathrm{Hb}$ levels and body mass index (BMI), waist and hip circumferences and body fat, while negative association was found with muscle mass in adult population [12]. Examination of anthropometric parameters and haematological parameters in 81 subjects, aged 18 to 22 years, showed that in males there was a positive correlation between weight and haematocrit and BMI and haemoglobin. In females height, weight, body surface and BMI did not show significant correlation with any of the blood parameters [6]. These results are in accordance with the results from this study.

Reports from previous studies have revealed that a low BMI is associated with iron deficiency anaemia [13]. There were also the reports of no association between the red blood cells' counts, haemoglobin concentration, haematocrit and BMI $[14,15]$. Overweight, high BMI or/and high body fat is associated with low haemoglobin level in adolescent girls, while in boys such association was not found [16]. An inverse relationship between body mass index (BMI) and serum ferritin was found [17]. In a study which was conducted on female medical students in India, significant negative correlation was found between $\mathrm{Hb}$ and weight, height, body fat and BMI (18). Results of a study which explored associations of haemoglobin level and the amount of fat and muscle in older adults ( $>65$ years) showed positive association of $\mathrm{Hb}$ level and muscle area, muscle density and muscle strength [19].

In this study, the investigated group consisted of healthy and physically active young subjects with predominantly optimal values of muscle mass and $\mathrm{BF} \%$, and very low prevalence of high $\mathrm{BF} \%$, which contributed to positive correlations between all body components (including the BMI) and $\mathrm{RBC}$ variables.

Maximal oxygen consumption (VO2max) is a cardio-physiological parameter which is a measure of aerobic capacity. The aerobic capacity depends on cardiovascular, respiratory, and haematological components in addition to oxidative mechanisms of muscles being exercised [20]. It has long been known that both body mass and lean body mass are strongly correlated with maximal oxygen uptake (VO2max) in man and animals [21]. Body composition, especially body fat component is one of the factors which contribute to lower oxygen consumption in women [22].

In prepubertal children, results in the literature are much more controversial than in adults. When body size is taken into account, few studies reported VO2max in boys and girls. Gender difference in oxygen consumption was reported as being lower in the female at older age, and these results are mainly explained by difference in body composition, especially in body fat mass (and body fat percent) [8]. In prepubertal children this gender difference in VO2max totally disappeared when normalized for LBM [23].

Maximal oxygen uptake can be limited by oxygen transport, delivery and extraction, which is the main function of haemoglobin i.e. red blood cells [24]. Haemoglobin mass (Hbmass) represents a major convective determinant of oxygen $(\mathrm{O} 2)$ supply to active muscle [25]. As such, 
Hbmass is often regarded as a key limiting factor to maximum O2uptake ( $\dot{\mathrm{V} O} 2 \mathrm{max}$ ), which in turn is a strong predictor of endurance performance [26]. HBmass was largely correlated $(\mathrm{r}=0.62)$ and moderate correlations were found between $[\mathrm{Hb}]$ and $\mathrm{MCHC}$ with specific aerobic fitness performance test in elite team players [27]. Athletes have considerably larger blood volumes than untrained individuals, and VO2 max is significantly related to total $\mathrm{Hb}$ content and blood volume in endurance athletes [28].

Mean values for $\dot{\mathrm{VO}} 2 \mathrm{max}$ in children, adolescents and adults are consistently greater in males than females, whether VO2max is expressed in absolute terms or relative to lean body mass [8]. Gender difference in body composition was implicated as a main factor for gender difference in maximal oxygen consumption. Expressing VO2 max relative to fat free mass or lean body mass did not eliminate these differences, although they were slightly reduced [29]. In an investigation of the relationship between cardiorespiratory fitness (CRF) and some anthropometric factors in children and adolescent in Bosnia and Herzegovina, it was found that CRF was associated with lower waist circumferences (WC) and higher waist to height ratio. Lower waist circumferences percentile was a significant determinant of good cardiorespiratory fitness in boys. Those with better CRF were more likely to be male and older, had a higher level of PA and lower central adiposity [30].

\section{CONCLUSIONS}

Our findings revealed that there are some expected positive correlations between lean body mass components, aerobic performance and $\mathrm{RBC}$ variables in boys. Body fat percent did not correlated to RBC variables, but was negatively correlated to ergometry results and VO2max. Our hypothesis that young athlete with higher lean body mass (muscular and bone mass) will have higher (better) RBC variables values was partially proved with our findings. In boys there were positive correlations between all body components and RBC variables, including the fat mass, with lowest level of correlation. In girls such associations were not found. Regarding the results of ergometry testing, higher body fat percent was associated with lower aerobic performance (exercise time and oxygen con- sumption) in boys. High body fat mass and high heart rate at rest are unwanted parameters for athletes, and our findings showed positive correlations between these parameters, which could indicate that boys with higher body fat percent have higher heart rate at rest and weaker aerobic performance. Weak positive correlations were found between haemoglobin and haematocrit and aerobic performance only in boys. In girls all correlations between body components and haematological and cardio-physiologic parameters were statistically non-significant, which could be result of lower level of physical activity in girls.

\section{REFERENCES}

1. Fulgoni LF, Agarwal S, Kelogg MD, et al. (2019). Establishing pediatric and adult $\mathrm{RBC}$ reference intervals with NHANES data using Piecewise regression. Am J of Clin Pathol 2019; 151: 128-142.

2. Horvath, A.R. From evidence to best practice in laboratory medicine. (2013). Clin Bioch Rev 2013; 34: 47-60.

3. Varamenti E, Nikolovski Z, Elgingo MI, et al. (2018). Training-induced variations in haematological and biochemical variables in adolescent athletes of Arab origin throughout an entire athletic season. J of Hum Kinetic 2018; 64: 123-135 doi: 10.1515/hukin-2017-0187.

4. Winsley R, Matos N. Overtraining and Elite Young Athletes. (2011). Medic Sport Sci 2011; 56: 97-105.

5. Souglis A, Travlos A. The influence of competitive activity on selected biochemical and haematological parameters of amateur soccer athletes. J of Phys Edu and Sport 2015; 15(1): 24-31.

6. Arifuddin MS. Hazari MAH. Does anthropometric measurements correlate with hematological parameters after the adolescent growth period. Physiol and Pharmacol, 2016; 20: 137-146.

7. Chmielewski P, Strzelec B, Chmielowiec J, et al. (2017). Association between body size and selected hematological parameters in men and women aged 45 and above from a hospitalized population of older adults: an insight from the Polish Longitudinal Study of Aging (19602000). Anthropol Rev, 2017; 80(2): 171-190.

8. Rowland T, Goff D, Martel L, et al. (2000). Influence of cardiac functional capacity on gender differences in maximal oxygen uptake in children. Chest 2000; 117: 629-635.

9. Jamshidi L, Karimi L, Seif A, et al. The relationship between anthropometric factors and iron deficiency anemia factors. Novelty in Biomed 2017; 2: 69-64. 
10. Pinhas-Hamiel RS, Newfield I, Koren A. et al. Greater prevalence of iron deficiency in overweight and obese children and adolescents. Int $\mathrm{J}$ Obes 2003; 27: 416-418.

11. Barazoni R, Cappelari GC, Semolic A, et al. (2014) The association between hematological parameters and insulin resistance is modified by BMI - Results from the North-East Italy MoMa population study. PloS ONE 2017-4; 9(7): e101590 doi: 10.1371/journal.pone. 011590

12. Auvinen J, Tapio J, Karhunen V. et alt. (2018). Lower hemoglobin levels associated with lower body mass index and healthier metabolic profile. Available at: http: //dx.doi.org/10.1101/472142. https: //www.biorxiv.org/content/biorxiv/early/2018/11/19/472142.full.pdf

13. Akramipour R, Rezaei M, Rahimi Z. Prevalence of iron deficiency anaemia among adolescent schoolgirls from Kermanshah, Western Iran. Hematology 2008, 13(6): 352-355. DOI: $10.1179 / 102453308 \times 343383$

14. Ajayi OI, Akinbo DB, Okafor AM. (2017). Correlation between $\mathrm{BMI}$ and hematological indices in young Nigerians with different hemoglobin genotypes. Am J of Biomed Sci 2017; 9(1): 38-46.

15. Akram G, Narjes N, Hassan-Ali, V. Association of Body Mass Index with Haemoglobin Concentration and Iron Parameters in Iranian Population, Hematology 2014; 52(5): 312-313. http: // dx.doi.org/10.1155/2014/525312

16. Bagni UV, Luiz RR, Veiga GV. (2013). Overweight is associated with low hemoglobin levels in adolescent girls. Obes Res Clin Pract 2013; 7: 218-29

17. Eftekhari M, Mozaffari-Khosravi H, Shidfar F. (2009). The relationship between BMI and iron status in iron-deficient adolescent Iranian girls. Pub Health and Nutr 2009; 12: 2377-81.

18. Acharya S, Patnaik M, Mishra SP, et al. Correlation of hemoglobin versus body mass i ndex and body fat in young adult female medical students. Nat J of Physiol and Pharamacol 2018; 8(10): 1371-1373.

19. Cesari M, Penninx B, Lauretani F, et al. (2004). Hemoglobin Levels and Skeletal Muscle: Results From the InCHIANTI Study. J of Gerontol, 2009; 59(3): 249-254. https: //doi.org/10.1093/ gerona/59.3.M249
20. Rodrigues AN, Perez AJ, Carletti L, et al. (2006). Maximum oxygen uptake in adolescents as measured by cardiopulmonary testing: a classification proposal. J of Ped (Rio J) 2006; 82(6): 426-30.

21. Kearns CF, McKeever JHA, Abe T, et al. Relationship between body composition, blood volume and maximal oxygen uptake. Eq Exerc Physiol 2002; 34: 485-490.

22. Falz R, Schulze A, Fikenzer S, et al. Hematological Parameters in Moderately Trained Students. CSM 2010; I, 4: 1-7.

23. Vinet A, Mandigout S, Nottin S, et al. Influence of Body composition, hemoglobin concentration, cardiac size and function of gender differences in maximal oxygen uptake in prepubertal children. CHEST 2003; 124: 1494-1499.

24. Tolle J, Waxman A, Systrom D. Impaired systemic oxygen extraction at maximum exercise in pulmonary hypertension. Med Sci Sport Exerc 2008; 40: 3-8.

25. Schmidt W, Prommer N. Impact of alterations in total hemoglobin mass on VO2 max. Exerc Sport Sci Rev 2010; 38(2): 68-75.

26. Levine BD. VO2max: what do we know, and what do we still need to know? J of Physiol 2008; 586(1): 25-34.

27. Brocherie F, Millet GP, Hauser A, et al. Assocoation of hematological variables with team-sport specicific fitness performance. PLOS ONE 2015; 10(12): e0144446. https: //doi.org/10.1371/journal.pone.0144446).

28. Henicke K, Wolfarth B, Winchenbach $\mathrm{P}$, et al. Blood volume and hemoglobin mass in elite athletes of difference disciplines. Int $\mathrm{J}$ of Sports Med 2001; 22(7): 504-512 DOI: $10.1055 / \mathrm{s}-$ 2001-17613

29. Saghiv MS, Sherve C, Sira DB, et al. Are there Differences between Adolescent Males and Females for Maintaining the Metabolic Cost at Maximal Oxygen Uptake? J Clin and Experim Cardiol 2017; 8: 519. doi: 10.4172/21559880.1000519

30. Pojskic H, Eslami B. Relationship Between Obesity, Physical Activity, and Cardiorespiratory Fitness Levels in Children and Adolescents in Bosnia and Herzegovina: An Analysis of Gender Differences. Front of Physiol 2018; 9: 1734. doi: 0.3389/fphys.2018.01734. 


\title{
Резиме
}

КОРЕЛАЦИИ МЕГ์У ПАРАМЕТРИТЕ НА ЦРВЕНИ КРВНИ КЛЕТКИ, КАРДИОФИЗИОЛОШКИ И АНТРОПОЛОШКИ ПАРАМЕТРИ КАЈ МЛАДИ СПОРТИСТИ

\author{
Јасмина Плунцевиќ Глигороска ${ }^{1}$, Сандра Дејанова $^{2}$, Јадранка Плавшиќ $^{3}$, Сања Манчевска $^{1}$ \\ ${ }^{1}$ Институт за физиологија, Медицински факултет, УКИМ, Скопје, РС Македонија \\ ${ }^{2}$ Општа болница „8 Септември“, Скопје, РС Македонија \\ ${ }^{3}$ Српски институт за спорт и спортска медицина, Белград, Р Србија
}

Цел: Да се утврдат и да се анализираат постојните релации меѓу антропометриските карактеристики, хематолошките и кардиофизиолошките параметри кај здрави и физички активни деца и адолесценти.

Материјал и метод: Во овој труд се иследувани 625 испитаници поделени во две групи според полот (410 машки и 215 женски, на возраст од 8 до 18 години). Во рамките на редовните преднатпреварувачки медицински прегледи, направена е анализа на телесниот состав по Матиегка, ергометриски тест според Брусов протокол и анализа на крвната слика.

Резултати: Двете групи покажаа позитивна корелација меѓу висината и тежината и RBC (црвени клетки) варијабли. Во групата девојчиња сите други антропометриски параметри (компоненти на телесниот состав) не покажаа значителна поврзаност со RBC-варијаблите. Кај момчињата сите телесни компоненти покажаа позитивна корелација со RBC-варијабли, но нивото на корелација беше најниско кај масната компонента. Кај двете групи, машката и женската, BF \% (процентот на масно ткиво) не покажа значителна корелација со ниту една RBC-варијабла. Кај момчињата BF \% покажа слаба негативна корелација со аеробните способности, времетраење на тестот (ЕT) и кислородна потрошувачка $(\mathrm{VO} 2 \mathrm{max})$ и тие изнесуваa $\mathrm{rs}=-0.41$ и $\mathrm{rs}=-0.39$. Чистата телесна маса (LBM) покажа слаба позитивна корелација со аеробните способности кај момчињата. Кај девојчињата немаше значителни корелации меѓу телесните компоненти и резултатите на ергометриското тестирање.

Заклучок: Нашите резултати укажуваат дека постојат очекувани корелации меѓу параметрите на телесниот состав, RBC-варијаблите и ергометриски варијабли кај машките испитаници, додека кај женските испитаници тие се од послаб интензитет или изостануваат.

Клучни зборови: млади спортисти, телесен состав, црвени крвни клетки, ергометрија, кислородна потрошувачка 